\title{
Expressional Analysis of Two Genes (Scd1 and /di1) Down-regulated by Starvation Stress
}

\author{
Junho Cho', Young-Sook Kwon ${ }^{2}$, Dong-II Kim ${ }^{3}$, Bok Jo Kim ${ }^{4}$ and Kisang Kwon ${ }^{4 *}$ \\ ${ }^{1}$ Department of Emergency Medicine, Inje University Haeundae-Paik Hospital, Busan 612-896, Korea \\ ${ }^{2}$ Department of Nursing, Joongbu University, Geumsan 312-702, Korea \\ ${ }^{3}$ Department of Health care \& biotechnology, College of Health \& Welfare, Kyungwoon University, Gumi 730-739, Korea \\ ${ }^{4}$ Department of Biomedical Laboratory Science, College of Health \& Welfare, Kyungwoon University, Gumi 730-739, Korea
}

Received March 28, 2014 /Revised July 24, 2014 / Accepted July 24, 2014

\begin{abstract}
Diet exerts a major stress on the body and may affect gene expression and physiological functions. Understanding of cellular responses during starvation is necessary in developing strategies to reduce damage caused by diet. In this study, we isolated 10 genes (Comt, RGN, Scd1, Temt, Idi1, Fabp5, Car3, Cyp2C70, Pinx1, and Poldip3) that are down-regulated in starvation and are closely related to liver metabolism. Water supply during starvation had no effect on the induction of apoptosis, autophagy, and ERQC. The genes down-regulated by starvation were associated with many related pathways rather than limited to the liver homeostasis pathway. Water supply during starvation is important. However, maintaining $\mathrm{NaCl}$ homeostasis is more important. The results are thought to be closely related to gender-specific metabolism in starvation and $\mathrm{NaCl}$.
\end{abstract}

Key words : Idi1, Scdl, starvation

\section{서 론}

비만이란 지방이 체내에 비정상적으로 축적됨으로 임하여 정상적인 생리 상태를 유지하기 어려운 것을 말한다. 체내에 서 대사에 사용되지 않은 지방이 피하층 혹은 내장 사이에 쌓이면 대사질환에 쉽게 노출되어 당뇨병, 고혈압, 고지혈증, 동맥경화, 퇴행성관절염, 수면 무호흡, 담석증, 지방간, 암 등 의 원인이 될 수 있다. 1997년 $\mathrm{WHO}$ 에서는 비만을 '치료를 해야 하는 질병’으로 규정하고 적극적인 치료를 권장하고 있 다. 우리나라도 1970년대 후반부터 급격하게 경제가 발전하면 서 소득이 늘어났고 기름진 음식을 많이 섭취하면서도 운동량 이 상대적으로 감소하면서, 현재는 성인 10 명 중 3 명 정도가 비만에 노출되고 있다. 비만해진 사람들은 어느 정도까지는 크게 자각하지 않고 생활하지만, 주위에서 일어나는 다이어트 열풍에 자신의 비만을 자각하게 되면 급속한 원상회복을 원하 게 된다. 그래서 짧은 시간 안에 체중을 감량할 수 있는 방법에 관심을 가지게 된다. 단시간의 집중적인 체중감소를 위한 다 이어트는 비타민, 무기질 등 필수 영양소를 섭취할 수 없고 근육량이 줄어 질병에 대한 저항력이 떨어지게 된다. 현대식

\section{*Corresponding author}

Tel : +82-54-479-1284, Fax : +82-54-479-1280

E-mail : ppkisang@empal.com

This is an Open-Access article distributed under the terms of the Creative Commons Attribution Non-Commercial License (http://creativecommons.org/licenses/by-nc/3.0) which permits unrestricted non-commercial use, distribution, and reproduction in any medium, provided the original work is properly cited.
단과 생활습관은 급격하게 신체대사에 원하지 않은 비만과 심장병계통의 질환을 유발하는 결과를 초래하게 되었다. 비록 비만과 관련된 대부분의 대사질환은 높은 수준의 phenylalanine을 포함하고 있는 음식물을 피하는 적절한 다이어트를 통해서 극복할 수 있으며 습식 칼로리를 제한하는 것은 분명 한 효과가 있다, 그러나 이와 같은 다이어트과정에서 일어나 는 생리적 반응의 분자기전은 불분명하다[5]. 본 연구는 다이 어트가 질병과 노화와 같은 급속한 대사변화의 진행에 미치는 영향을 이해하기 위하여, 급속한 영양상태의 변화가 조절하는 유전자 및 신호전달기전에 관련된 실마리를 제공하는 것이다.

포유실험동물에 비해서 사육조건과 분석이 용이한 누에 (silkworm)를 사용하여 만들었다. 누에의 fat body는 포유동 물의 liver에 해당하는 기능을 가지고 있으며 대사적으로 중요 한 대부분의 유전자와 대사기전을 공유하고 있다. 누에의 fat body를 현미경하에서 분리하여 glucose free medium에서 24 시간 후 배양한 후에 total RNA를 분리하여 DD-PCR실시하여 차별적으로 발현이 상승하는 유전자를 분리하였다. 이렇게 분 리된 유전자중 Scd1과 Idi1을 대상으로 in vivo/n vitro에서 유 전자 발현을 조사하고 그들 조직의 변화를 관찰한다.

Stearoyl-Coenzyme A desaturase 1 (ScdI)은 endoplasmic reticulum membrane에 존재하는 iron-containing 효소로서 fatty acid metabolism에서 Stearoyl-CoA의 double bond형 성을 담당하며 주산물은 stearic acid의 desaturation에 의해 서 생산하는 oleic acid이다. Oleic acid생산율은 cell membrane fluidity and signal transduction을 통해서 세포성장과 분화에 깊이 관계가 있다[3]. 지금까지 4 개의 Scd isoform이 
알려지고 있다, 그 중에서 human에는 $S c d 1$ 과 $S c d 5$ 가 존재한 다. Scd1유전자는 359 amino acids $(41,523 \mathrm{Da})$ 를 chromosome 4 에 코드하고 있으며 전사물로는 3.9 and $5.2 \mathrm{~kb}$ 을 만든 다[6]. 아래의 그림과 같이 $S \mathrm{Cdl}$ 의 발현에 따라서 세포내 cholesterogenesis에 많은 영향을 미친다. Scd1이 상승발현하면 liver X receptor (LXR)의 발현이 상승하여 bile acid생산이 증가하는 반면에 $S c d 1$ 이 하강발현하면 triglyceride를 통한 very-low-density lipoprotein (VLDL)과 cholesterol ester의 생산이 증가된다. 이런 과정을 통해서 ScdI은 cholesterogenesis와 lipogenesis간의 균형을 유지하는데 크게 관여하 는 효소이다[4]. Scd1결손에 의한 질환으로는 systemic primary carnitine deficiency disease (plasma membrane을 통과 하는 carnitine관련 transporter의 결함이 원인이 되어 fatty acid transport에 태생적인 결함을 가지는 질환)와 familial combined hyperlipidemia (혈중 high cholesterol과 high blood triglyceride가 원인이 되어서 early heart attack을 가 지는 유전질환)이 알려지고 있다[1]. Isopentenyl-diphosphate delta isomerase 1 (Idi1)은 isopentenyl pyrophosphate isomerase; IPP로도 불리며 227 amino acids $(26,319 \mathrm{Da})$ 로 구성된 peroxisomally-localized enzyme으로 isopentenyl diphosphate를 highly electrophilic isomer인 dimethylallyl diphosphate (DMAPP, cholesterol의 전구체)로 전환을 촉매한 다[2]. Idi1의 isomerization기능은 mevalonate pathway를 통한 isoprenoid 생합성의 중요한 단계이다[9]. Cholesterol biosynthesis와 geranylgeranyldiphosphate biosynthesis I (via mevalonate)에 관여하기 때문에 Idi1의 결손에 의해서 생기는 질환으로는 Zellweger syndrome (intracellular peroxisome 의 감소 혹은 소멸)과 neonatal adrenoleukodystrophy (peroxisome biogenesis결함인 autosomal recessive질환)가 알려지고 있다[13]. 기능연구를 위하여 human Idi1의 구조가 $1.7 \mathrm{~A}$ resolution 수준에서 결정되었다[14].

\section{재료 및 방법}

\section{실험동물 \& 세포배양}

Rat는 $200 \mathrm{~g}$ 정도의 암, 수를 사용하였으며, 실험 전날 공급 받아 하룻밤 안정화시켰다. Rat의 각종 장기는 도살 후 즉시 냉각된 각각의 buffer (4\% paraformaldehyde 용액; 조직실험, $\mathrm{RNAzol}^{\mathrm{TM}} \mathrm{B}$; total RNA분리)에 보관하였으며, 누에(Bombyx mori)는 충남 잠사곤충사업장(장장 최택용)에서 공급받았으 며, 누에의 fat body는 광학현미경하에서 순수하게 분리하여 rat와 동일하게 total RNA를 분리하였다. PCCL3 배양세포(rat thyroid cell line)는 5\% 우혈청을 포함한 Coon's modified me$\mathrm{dia}$ 에서 배양하였다. 배양조건은 $37^{\circ} \mathrm{C}, 5 \% \mathrm{CO}_{2}, 95 \%$ 이상의 적당한 습도를 유지하였다. 신선한 배지를 2일 간격으로 교체 하며 배양하였으며, 1 주일에 한 번씩 계대 배양하였다. 실험에
쓰이는 세포는 70 90\%의 충실도를 보이는 세포를 사용하였다.

\section{Total RNA 분리}

Total RNA 분리에는 RNAzol ${ }^{\mathrm{TM}} \mathrm{B}$ kit (Tel-Test, Inc. TX,

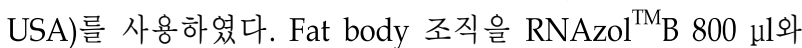
함께 $1.5 \mathrm{ml}$ tube에 넣고 얼음 위에서 덩어리가 없어질 때까지 homogenization 시킨 다음 RNA 추출 용액 $200 \mu 1$ 를 첨가하 여 약 30 초간 교반 후 상온에서 5 분간 방치하였다. $12,000 \mathrm{xg}$ $\left(4^{\circ} \mathrm{C}\right)$ 에서 15 분간 원심 분리하여 얻은 $500 \mu \mathrm{l}$ 의 상층액에 500 $\mu 1$ 의 isopropanol을 첨가하여 $4{ }^{\circ} \mathrm{C}$ 에서 15 분간 방치 후 다시 $12,000 x \mathrm{~g}\left(4^{\circ} \mathrm{C}\right)$ 에서 15 분간 원심 분리하여 튜브의 바닥에서 백황색의 침전물을 얻었다. 이 침전물에 $75 \%$ ethanol $500 \mu \mathrm{l}$ 를 첨가하고 잘 교반하여 $7,500 \mathrm{x} \mathrm{g}\left(4^{\circ} \mathrm{C}\right)$ 에서 8 분간 원심 분리 하여 RNA를 얻었으며 total RNA의 질량은 spectrophotometer로 측정하였다. RNA를 다룰 때는 항상 장갑을 착용 하였고 diethylpyrocarbonate (DEPC) 처리된 물을 사용하였 으며, $-20{ }^{\circ} \mathrm{C}$ 에서 $1 \mathrm{mM}$ 의 $\operatorname{EDTA}(\mathrm{pH}$ 7)를 함유한 $\mathrm{DW}$ 에 보관하였다.

\section{DD-PCR}

$\mathrm{mRNA}$ level의 발현 정도에 차이를 보이는 것을 찾기 위해 서 GeneFishing DEG premix kit (Seegene Co.)를 이용하여 DD-PCR을 시행한다. Harvest 한 세포에서 얻은 total RNA $3 \mu \mathrm{g}$ 을 $10 \mu \mathrm{M}$ 의 dT-ACP1 $2 \mu \mathrm{l}$ 와 함께 $80^{\circ} \mathrm{C}$ 에서 3 분 간 가열하여 denature 시킨 후, cold ice에서 급랭한다. $4 \mu \mathrm{l}$ 의 $5 \times$ RT buffer, $4 \mu \mathrm{l}$ 의 dNTP (each $2.5 \mathrm{mM}$ ), $0.5 \mu \mathrm{l}$ 의 RNase inhibitor $(40 \mathrm{u} / \mu \mathrm{ll}), 1$ unit M-MLV reverse transcriptase (200 $\mathrm{u} / \mu \mathrm{ll}$ 를 가하고 총 반응액이 $20 \mu \mathrm{l}$ 가 되도록 조절한 후 $42^{\circ} \mathrm{C}$ 에 서 90분 동안 반응시켜 cDNA를 합성한다. GeneFishing $\mathrm{PCR}$ 를 위하여 $\mathrm{dT}-\mathrm{ACP} 2$ 와 각각의 arbitrary $\mathrm{ACP}$ 를 primer 로 하여 $\mathrm{cDNA}$ 를 증폭시키고 $2 \%$ 의 agarose gel에서 $\mathrm{PCR}$ product를 전기영동하여 차별적으로 발현하는 fragment를 확인 후 subcloning, sequencing과정을 거쳐 유전자를 확인한 다.

\section{RT-PCR}

역전사반응은 $42^{\circ} \mathrm{C}$ 에서 90 분간, RTase 비활성화 반응은 9 $4^{\circ} \mathrm{C}$ 에서 2 분간 수행하였으며 이후 $4^{\circ} \mathrm{C}$ 에서 보관하였다. 위의 과정에 의해 합성된 $\mathrm{cDNA}$ 는 $\mathrm{MJ} \mathrm{Mini}^{\mathrm{TM}}$ Personal Thermal Cycler (BIO-RAD, USA) PCR 기기를 이용하여 RT-PCR을 수 행하였으며 사용된 primer는 모두 바이오니아(대전)에서 합 성하여 사용하였다. RT-PCR의 반응 조건은 $94^{\circ} \mathrm{C}$ 에서 5 분 동 안 초기 변성을 시켜준 후 $94^{\circ} \mathrm{C}$ 에서 30 초, $56^{\circ} \mathrm{C}$ 에서 30 초, $72^{\circ} \mathrm{C}$ 에서 40 초로 29 회 반복한 후 마지막 합성은 $72^{\circ} \mathrm{C}$ 에서 5 분으로 수행하였다. 증폭된 PCR 산물을 $1 \%$ agarose gel에 전기 영동시켜 확인하였다. RT-PCR에 사용된 primer는 아래 
와 같다. 실험에서 특별하게 언급하지 않은 시약은 Sigma사 에서 구입하여 사용하였으며 최소 3회 최대 6회 동일한 실험 을 반복하였다. 본 실험에 사용된 PCR primer는 다음과 같다. Scd1-F; 5'-tcctgctcatgtgcttcatc-3', Scd1-R; 5'-ggatgttctcccgagattga-3', Idi1-F; 5'-gtcaaacgagcagcacagag-3', Idi1-R; $5^{\prime}$-gatccggattcagggttaca- $3^{\prime}$.

\section{Western blotting}

Protein electrophoresis kit (ATTO Co., Japan)를 사용하여 $12 \% \mathrm{SDS}-\mathrm{PAGE}$ 에 준비된 sample을 전기영동 하였다. 전기영 동이 끝난 후 transfer kit (Bio-RAD, USA)를 사용하여 gel의 protein을 PVDF cell membrane (PALL corporation, USA)에 transfer buffer (20 mM Tris-HCl, $150 \mathrm{mM}$ glycine, 20\% methanol, $\mathrm{pH}$ 8.3)를 사용하여 transfer하였다. Transfer가 끝난 후 membrane을 PBST (PBS, 0.05\% Tween20)와 5\% skim milk를 사용하여 상온에서 1시간 동안 blocking하였다. Blocking이 끝 난 후 1차 반응 시킬 때에는 PBST와 5\% skim milk에 1:500 $1: 2,000$ 의 비율로 희석하여 $4^{\circ} \mathrm{C}$ 에서 3 시간 동안 반응시켰다. 1 차 항체 반응이 끝난 후 membrane을 PBST로 10 분씩 5회 상온에서 shaker를 사용하여 세척하였다. 세척이 끝난 후 2 차 항체를 반응 시킬 때에는 PBST에 1:2,000의 비율로 희석하 여 상온에서 1 시간 동안 반응 시켰으며, 반응이 끝난 후 membrane을 PBST로 10분씩 5회 상온에서 shaker를 사용하여 세척하였다. 세척이 끝난 후 West save (Lab Frontier, Korea) 를 사용하여 발색반응을 유도한 후 X-ray film에 감광하여 결과를 분석하였다.

\section{Immunofluorescence}

Paraffin section tissue를 Deparaffin (Zylene $15 \mathrm{~min}, 2$ time)과 rehydration (EtOH $100 \%-95 \%-90 \%-80 \%-70 \%$, 각각 1 $\mathrm{min}$ )한 다음에 $\mathrm{DW}$ 로 $5 \mathrm{~min}$ 간 washing한다. $0.01 \mathrm{M}$ Citrate buffer (pH 6.0) $4 \mathrm{~min}, 20$ 분 동안 antigen retrieval을 실시한 후에 $0.05 \mathrm{M} \mathrm{PBS}$ 로 3 회 각 10 분간 washing한다. 비특이적 반 응을 억제하기 위해서 normal serum blocking을 30 분간 실시 한다. 조직이 마르지 않게 해야 하여 조직 크기에 알맞게 dakopen으로 테두리를 두껍게 그려 dakopen을 말린 후 각 슬라 이드에 50 100 $\mu 1$ 씩 분주한다. 반응액(3\% triton $100 \mu \mathrm{l}$, serum $50 \mu \mathrm{l}, \mathrm{PBS} 850 \mu \mathrm{l} / 1 \mathrm{l}) 1 \mathrm{st} \mathrm{Ab}$ 와 overnight 반응시킨 후 0.05 $\mathrm{M} \mathrm{PBS}$ 로 10분 간 3회 washing한다. Cy-biotin $\mathrm{Rb}(1 / 500)$, $2 \mathrm{hr}$ [Cy-conjugated anti-rabbit IgG] 후에 위의 반응액으로 10 분간 3회 washing한다. $2 \mathrm{nd} \mathrm{Ab}$ 와 overnight 반응시킨 후 $0.05 \mathrm{M} \mathrm{PBS}$ 로 10분간 3회 washing한다. Biotinylated Anti-M IgG [1/200]을 2시간 반응시킨 후에 0.05 M PBS로 다시 10 분 간 3 회 washing한다. $\mathrm{DW}$ 로 수세 후 70\%-80\%-90\%-95\%-100\% EtOH washing을 각각 1분간 실시 한 다음에 zylene을 15 분간 처리한 후 mounting을 한다.

\section{결 과}

누에 5 령 1 일의 몸무게는 $0.8 \mathrm{~g}$ 이지만, 뽕잎을 먹는 양이 급격히 늘면서 5령 2 일째는 $1 \mathrm{~g}, 5$ 일- $2.8 \mathrm{~g}$, 6일-3 g, 8 일-4.5 $\mathrm{g}$ 로 급격하게 증가한다. Starvation 실험은 5령 3일되는 누에 를 사용하였다, 하룻밤 동안 뽕잎을 공급하지 않는 starvation 처리를 하면 약 $30 \%$ 의 몸무게감소를 보였다[10]. 이후의 실험 은 누에의 fat body조직을 사용하여 필요한 단백질과 total RNA분리하였다. 누에를 핀으로 고정하여 움직이지 못하게 한 다음에 등 쪽의 피부를 longitudinal section한다. 몸의 대부 분을 차지하고 있는 장을 제거한 후에 피부에 붙어있는 신경 관을 핀셋으로 제거한다. 누에의 꼬리피부에 붙어있는 fat body 조직을 yellow chip으로 끌어 모은 다음에, 실체현미경 으로 cold PBS 속에서 fat body 조직 이외의 물질을 제거하여 순수한 누에 fat body 조직을 모아서 $-80^{\circ} \mathrm{C}$ 에서 다음 실험 때 까지 보관한다. RNAzol ${ }^{\mathrm{TM}} \mathrm{B}$ Kit를 사용하여 누에 total RNA 를 정제 후에 GeneFishing DEG premix kit (Seegene Co.)를 사용하여 DD-PCR을 시행하였다. GeneFishing DEG premix kit는 mammalian 유래의 genome을 대상을 만든 것이지만 예비실험결과 누에에서도 신뢰할 수 있을 정도로 up-/down-regulation이 확인되어 본 실험에 사용하게 되었 다. 아래와 같이 down-regulation되는 유전자 10개를 분류하 였다. Catechol- O-methyltransferase (Comt $)$, Regucalcin (senescence marker protein-30) (RGM), Stearoyl-Coenzyme A desaturase $1(S c d t)$, Thioether S-methyltransferase $(T e m t)$, Isopentenyl-diphosphate delta isomerase 1 (Idii), Fatty acid binding protein 5, epidermal (Fabp5), Carbonic anhydrase 3 (Car3), Cytochrome P450, family 2, subfamily c, polypeptide 70 (Cyp2c70), PIN2/ TERF1 interacting, telomerase Inhibitor 1 (Pinx 1 , Polymerase (DNA-directed), delta interacting protein 3 (Poldip3).

Starvation에 의해서 Poldip3을 제외한 9개 유전자는 liver에 서 약하게 발현하였다. 특히 Cyp2c70은 starvation에 의해서 liver특이적으로 발현하였다. Scd1은 24시간 starvation에서 가 장 강하게 하강발현하였고 Idi1은 4시간 starvation이후부터 하강발현하였다. Starvation에 의해서 하강 발현하는 유전자 로서 이후의 실험에서는(stearoyl-coenzyme A desaturase 1, Scd1), (isopentenyl-diphosphate delta isomerase 1, Idi1)을 대 상으로 정한 다음 Scdl, Idi1유전자발현이 단백질발현까지 연 결되는 것을 Western blotting과 형광현미경으로 확인하였다 (data not shown). Starvation에 의한 Scdl, Idi1유전자의 발현 이 타 장기에 비하여 liver에서 강하게 발현하는 것을 알았다. 이때에 liver가 받는 stress 정도를 알기 위하여 endoplasmic reticulum (ER) stress chaperone, apoptosis (Bax, Bcl2)와 autophage (LC3a, Beclin)관련 인자들의 발현변화를 측정하였 다. 암수 동일하게 ER stress chaperone, apoptosis와 auto- 
A

\begin{tabular}{|c|c|c|c|c|c|c|}
\hline \multicolumn{7}{|c|}{ \#. 11 (Scd1) } \\
\hline & \multicolumn{3}{|c|}{ Male (2Ds) } & \multicolumn{3}{|c|}{ Female (2Ds) } \\
\hline & c & F- & $\begin{array}{l}\text { W- } \\
\text { F- }\end{array}$ & c & F- & $\begin{array}{l}\text { W- } \\
\text { F- }\end{array}$ \\
\hline \multicolumn{7}{|l|}{ Thymus } \\
\hline Liver & - & - & - & - & - & \\
\hline Muscle & - & & & - & & \\
\hline A.T & - & & - & - & - & - \\
\hline
\end{tabular}

B

\begin{tabular}{|l|c|c|c|c|c|c|}
\hline \multicolumn{9}{|c|}{ \#. 13 (idi1) } \\
\hline & \multicolumn{3}{|c|}{ Male (2Ds) } & \multicolumn{2}{l|}{ Female (2Ds) } \\
\hline & C & F- & W- & C & F- & W - \\
& & & F- & & & F- \\
\hline Thymus & - & - & - & - & - & - \\
\hline
\end{tabular}

Fig. 1. Starvation conditions by a variety of changes in the mRNA expression of two genes. (A), (B) Two days starvation with water (F) or without (F-W) changes Scdl/1di mRNA expression in the various rat organs of the male and female.

phage관련 인자들의 유의한 유전자의 발현변화는 관찰되지 않았다(data not shown).

Starvation 동안에 물 공급이 우/송에서Scd1, Idi1유전자의 발현에 미치는 영향을 알기 위하여 2일간 starvation동안 에 물 공급군과 물을 공급하지 않는 군으로 나누어 관찰하였다. Scd1 유전자발현은 starvation에 의해서 우/송에서 동일하게 liver, muscle에서 물이 공급될 때보다가 물이 공급되지 않는 상태에서 더욱 하강발현하였다. 그러나 Idi1유전자는 우/周에 서 동일하게 물 공급에 의한 주목할 만한 유전자발현변화가 나타내지 않았다(Fig. 1).

개체에서 starvation처리시간에 의한 Scd1, Idi1유전자 발현 변화를 알기 위하여, rat를 1-3일간 starvation 시킨 뒤에 각종 장기에서 Scdl, Idi1유전자의 발현을 조사하였다. Fig. 2에서
보는 것과 같이, 유전자 $S c d 1$ 의 발현은 starvation에 의해서 cerebral cortex와 kidney에서는 변화가 없지만 cerebellum에 서는 2일째에 발현이 완전히 멈추고, thymus와 muscle에서는 3 일까지 순차적으로 하강하였다. Heart에서는 starvation 1일 부터 급격하게 $S \mathrm{cdl}$ 의 발현이 하강하였다. 유전자 Idi1의 발현 은 $S c d 1$ 유전자와 같이 심한 발현변화보다는 cerebellum, thymus, liver, lung, heart에서 starvation 1-3일 동안에 점차적으 로 발현이 하강하였다.

간헐 starvation에 의한 $S c d l, I d i 1$ 유전자의 발현양상을 관찰 하였다. 2일간 starvation 군과 2일간 starvation후 1 일간 먹이 를 공급한 군과 2 일간 starvation +1 일간 먹이를 공급 +2 일간 starvation한 군으로 나누었다. 유전자 $S c d 1$ 의 발현은 cerebellum의 경우는 2일간 starvation 군과 2일간 starvation후
A

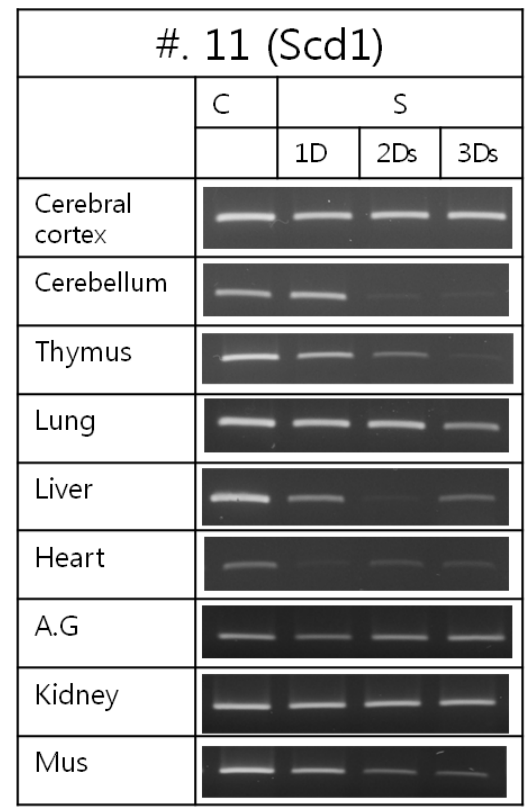

B

\begin{tabular}{|c|c|c|c|}
\hline \multicolumn{4}{|c|}{ \#. 13 (idi1) } \\
\hline & C & $S$ & \\
\hline & $1 \mathrm{D}$ & $2 \mathrm{Ds}$ & 3Ds \\
\hline $\begin{array}{l}\text { Cerebral } \\
\text { cortex }\end{array}$ & -- & - & - \\
\hline Cerebellum & - & - & 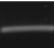 \\
\hline Thymus & -- & - & 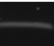 \\
\hline Lung & -- & - & 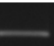 \\
\hline Liver & - & 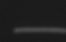 & \\
\hline Heart & - & - & \\
\hline A.G & - & 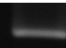 & \\
\hline Kidney & - & - & - \\
\hline Mus & - & - & 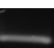 \\
\hline
\end{tabular}

Fig. 2. Starvation changes the expression of two genes in the various rat organs. (A) Starvation (1-3 day) changes Scdl mRNA expression in the various rat organs. (B) Starvation (1-3 day) changes Idi1 mRNA expression in the various rat organs. The experiments were performed three times and represent resulting above fig is one of them. 
1 일간 먹이를 공급한 군에서 발현이 약해진 후 2 일간 starvation +1 일간 먹이를 공급 +2 일간 starvation한 군에서 control과 같은 수준 정도의 발현을 보였다. Thymus에서는 2 일 간 starvation +1 일간 먹이를 공급한 군에서 가장 강한 발현을 보였다. Liver에서는 2일간 starvation에 의해서 발현이 완전 히 없어진 후에 다시 1 일간 먹이를 공급하면 정상발현으로 돌아왔다, 다시 2일간 starvation하면 발현이 다시 완전히 살 아졌다. Muscle에서는 2일간 starvation후에 control보다가 강한 발현을 보이지만 2 일간 starvation +1 일간 먹이를 공급 +2 일간 starvation한 군에서 발현이 완전히 살아졌다. Adipo tissue에서는 starvation이 시작되면 발현이 거의 살아졌다. 유전자 Idi1의 발현은 간혈 starvation에 크게 연관된 발현형 태를 보이지는 않았다(cerebellum, thymus, lung), 그러나 liv$\mathrm{er}$ 에서는 2 일간 starvation +1 일간 먹이를 공급에 의해서 발 현이 원상태로 회복되었으나 adipo tissue에서는 부분적인 회 복이 관찰되었다(Fig. 3). 물과 함께 생체항상성을 유지하기 위하여서는 $\mathrm{NaCl}$ 는 필수적이다. Starvation중 $\mathrm{NaCl}$ 에 의한
$S c d 1, I d i 1$ 유전자의 발현양상의 변화를 관찰하였다. $\mathrm{NaCl}$ 공 급에 의한 발현차이를 우/令구별하여 관찰하였다. 유전자 $S c d 1$ 의 발현은 송의 경우 $\mathrm{NaCl}$ 공급으로 cerebellum, thymus, muscle, lung 에서는 발현이 유지되었으며, liver에서는 $\mathrm{NaCl}$ 공급과 관계없이 하강발현을 보였다. 우의 경우는 $\mathrm{NaCl}$ 공급에 의해서 유의할만한 $S c d 1$ 의 발현변화를 보이지 않았 다. 유전자 Idi1의 발현은 우/송에서 동일하게 $\mathrm{NaCl}$ 공급에 따른 특이적인 발현변화가 관찰되지 않았다(Fig. 4).

\section{고 찰}

일반적으로 modern diet (restricting caloric intake)는 oxidative stress, genome integrity, endocrine signaling이 관여 하여서 급격한 aging을 피할 수 있고 life span을 연장할 수 있다는 많은 증거가 제시되고 있다[6, 7]. 비록 어떤 종류의 대사결함은 식사량을 제한(특히, 높은 수준의 phenylalanine) 하는 적절한 dietary modification에 의해서 향상될 수도 있지

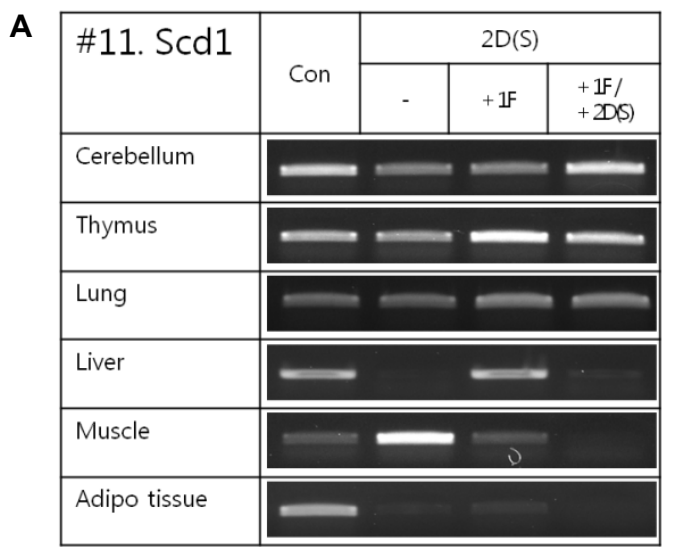

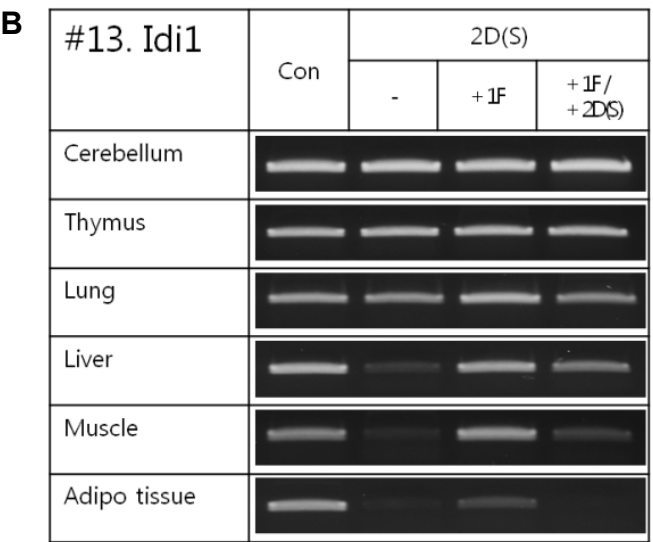

Fig. 3. Intermittent starvation changes $S c d 1 /$ di1 mRNA expression in the various rat organs. 2D; 2 day starvation, 2D+1F; 2 day starvation +1 day feed, $2 \mathrm{D}+1 \mathrm{~F}+2 \mathrm{D} ; 2$ day starvation +1 day feed +2 day starvation). The experiments were performed three times and represent resulting above fig is one of them.

A

\begin{tabular}{|c|c|c|c|c|c|c|}
\hline \multirow[t]{3}{*}{$\# 11$. Scd1 } & \multicolumn{3}{|c|}{ Male } & \multicolumn{3}{|c|}{ Female } \\
\hline & \multirow{2}{*}{ Con } & \multicolumn{2}{|c|}{$2 D(S)$} & \multirow{2}{*}{ con } & \multicolumn{2}{|c|}{$2 \mathrm{D}(\mathrm{S})$} \\
\hline & & $+\mathrm{W}$ & $+\mathrm{NaCl}$ & & $+W$ & $+\mathrm{NaCl}$ \\
\hline Cerebellum & 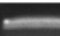 & 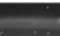 & 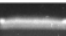 & 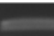 & 5 & 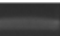 \\
\hline Thymus & 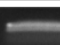 & $=$ & & & $=$ & \\
\hline Lung & 2 & 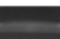 & $\longrightarrow$ & & 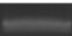 & \\
\hline Liver & 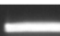 & & & & & \\
\hline Kidney & & & & & 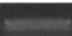 & 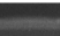 \\
\hline Muscle & 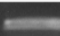 & & $=$ & & 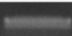 & 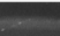 \\
\hline
\end{tabular}

B

\begin{tabular}{|c|c|c|c|c|c|c|}
\hline & \multicolumn{3}{|c|}{ Mail } & \multicolumn{3}{|c|}{ Femail } \\
\hline & \multirow{2}{*}{ con } & \multicolumn{2}{|c|}{$2 D(S)$} & \multirow{2}{*}{ con } & \multicolumn{2}{|c|}{$2 D(S)$} \\
\hline & & $+\mathrm{W}$ & $+\mathrm{NaCl}$ & & $+\mathrm{W}$ & $+\mathrm{NaC}$ \\
\hline Cerebellum & \multicolumn{3}{|c|}{$=2$} & \multicolumn{3}{|c|}{ 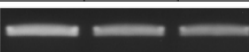 } \\
\hline Thymus & \multicolumn{3}{|c|}{ - } & \multicolumn{3}{|c|}{$x_{n}=$} \\
\hline Lung & \multicolumn{3}{|c|}{ 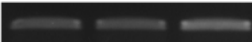 } & \multicolumn{3}{|c|}{ 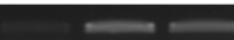 } \\
\hline Liver & \multicolumn{3}{|c|}{$=$} & \multicolumn{3}{|c|}{$=$} \\
\hline Kidney & \multicolumn{3}{|c|}{ 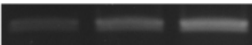 } & \multicolumn{3}{|c|}{$3=$} \\
\hline Muscle & \multicolumn{3}{|c|}{$=$} & \multicolumn{3}{|c|}{ 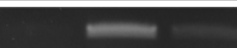 } \\
\hline
\end{tabular}

Fig. 4. The effect of $\mathrm{NaCl}$ on the starvation in male and female. Starvation with water only $(+\mathrm{W})$ or water including $1 \%+\mathrm{NaCl}$ $(+\mathrm{NaCl})$ changes Scd1/dil mRNA expression in various rat organs of the male and female. The experiments were performed three times and represent resulting above fig is one of them. 
만, 근본적으로 starvation을 바탕으로 하는 modern diet는 질 병은 아닌 원하지 않는 대사불균형을 초래하는 경우가 많다. 이런 상태가 지속적으로 반복적으로 일어나면 malnutrition상 태가 되어 obesity와 cardiovascular diseases가 될 수 있다. Malnutrition의 정의는 에너지, 단백질, 타 영양분이 몸의 기능 과 의학적인 문제를 일으킬 수 있을 정도로 과다하거나 부족 한 경우를 말한다. Malnutrition은 overnutrition 결과 obesity 가 되는 것과 undernutrition 결과 marasmus와 Kwashiorkorlike malnutrition으로 구별한다[11]. BMI [body mass index, weight $(\mathrm{kg}) /$ body height $\left.{ }^{2}\left(\mathrm{~m}^{2}\right)\right]$ 1.85이하는 severely underweight, 20이하는 underweight, 20 25는 건강한 상태, 25 30 은 overweight, 30 35는 obesity I, 35 40은 obesity II, 40 이상 은 obesity III군으로 분류한다. 일반적으로 short starvation 은 $\leq 72$ 시간이며 long starvation은 $\geq 72$ 시간을 의미한다. Short starvation동안에는 먼저 근육이 분해되어 liver의 gluconeogenesis에 의해서 만들어진 glucose가 brain에 사용되 며 glycogen분해에 의해서 생성된 glucose와 fat분해에 의해 서 생성된 FA와 glycerol이 말단에 전달된다[12]. Long starvation 동안에는 short starvation동안과 같이 근육이 분해되 어 liver의 gluconeogenesis에 사용되며 liver에서 ketogenesis가 일어나 생성된 glucose와 ketone body가 brain에 전달되며 더욱 많은 양의 fat이 분해되어서 말단과 liver에 FA와 glycerol형태로 전달된다. 몸은 short- \& long-term starvation에 탄수화물, 단백질, 지질을 전환시켜서 adaption 한다. 더욱 효율적인 적응법은 에너지 사용을 최저화하여 탄 수화물, 단백질, 지질을 전환을 감소시키는 것이다. Dietary modification이 어떤 분자기전이 작동하여 aging을 억제하고 질병을 촉진시키는지를 규명할 수 있는 실마리를 제공하는 것이다.

Starvation에 의해서 Poldip3을 제외한 9개의 유전자는 liver 에서 약하게 발현하였다. 이 결과는 starvation에 의한 유전자 발현변화는 대부분 liver 대사변화와 관련된 것으로 볼 수 있 다. Scd1은 starvation에 의해서 24시간에서만 발현이 하강하 였고 Idi1은 4시간 starvation이후 발현이 하강하였다. 그래서 $S c d 1$ 을 starvation에 의해서 장기적으로, Idi1을 starvation에 의해서 단기적으로 하강 발현하는 유전자의 예로서 이후의 실험을 하였다. 각각의 우/송 rat를 물을 공급하는 것 물을 공급하지 않는 군으로 나누어 2일간 starvation한 결과는 물 공급에 의한 우/송동일하게 apoptosis, autophage, $\mathrm{ERQC}$ 유 도와는 직접적인 상관성은 떨어지는 것으로 보인다. 그러나, Scdl유전자발현은 우/송 동일하게 starvation과 물 공급 제한 에 의해서 발현이 하강하는 경향이지만 우의 경우가 송에 비 하여 물 공급에 영향을 덜 받는 것으로 생각된다. 특히, 물 공급 제한은 Idi1유전자발현에 영향을 전혀 미치지 않았다. Starvation에 의해서 유전자 $S c d 1$ 의 발현은 cerebellum, thymus, lung, heart, muscle에서 하강하였고, 유전자 Idi1의 발현
은 cerebellum, thymus, lung, heart에서 starvation에 의해서 하강 발현하였다. 이 결과는 starvation에 의한 유전자발현조 절이 liver에 국한된 것이라기보다는 개체의 항상성유지에 관 련 많은 pathway가 관련되어있는 것으로 판단된다. 간헐 starvation에 의한 Scdl, Idi 1 유전자의 발현양상을 관찰하였다. 2 일 간 starvation 군과 2일간 starvation후 1일간 먹이를 공급한 것과 2일간 starvation+1일간 먹이를 공급 +2 일간 starvation 한 군으로 나누었다. 유전자 $S c d 1$ 의 발현은 cerebellum, thy$\mathrm{mus}$ 에 국한하여 강한 발현변화를 보였다. 이 결과로 장기간 의 간혈 starvation은 glucose소비가 많은 brain과 면역기능 조절에 중요한 thymus의 정상기능에 영향을 미칠 수 있는 것으로 보인다. 유전자 Idi1의 발현은 간혈 starvation에 크게 연관된 발현형태를 보이지는 않았다. 유전자 $S c d 1$ 의 경우는 우보다가 송이 민감한 반응을 보이는 것으로 보아 우/令의 성 특이적인 대사에 starvation과 $\mathrm{NaCl}$ 이 밀접한 관계가 있 는 것으로 보인다. 유전자 Idi1의 발현은 우/송에서 특이적인 발현변화가 관찰되지 않았다. Starvation시 물 공급도 중요하 지만 개체의 항상성유지에 $\mathrm{NaCl}$ 공급이 중요한 결과를 얻었 다.

\section{References}

1. Attie, A. D., Flowers, M. T., Flowers, J. B., Groen, A. K., Kuipers, F. and Ntambi, J. M. 2007. Stearoyl-CoA desaturase deficiency, hypercholesterolemia, cholestasis, and diabetes. Nutr Rev 65, S35-38.

2. Berthelot, K., Estevez, Y., Deffieux, A. and Peruch, F. 2012. Isopentenyl diphosphate isomerase: A checkpoint to isoprenoid biosynthesis. Biochimie 94, 1621-1634.

3. Flowers, M. T. and Ntambi, J. M. 2008. Role of stearoyl-coenzyme A desaturase in regulating lipid metabolism. Curr Opin Lipidol 19, 248-256.

4. Lauressergues, E., Bert, E., Duriez, P., Hum, D., Majd, Z., Staels, B. and Cussac, D. 2012. Does endoplasmic reticulum stress participate in APD-induced hepatic metabolic dysregulation? Neuropharmacology 62, 784-796.

5. MacDonald, A., Rocha, J. C., van Rijn, M. and Feillet, F. 2011. Nutrition in phenylketonuria. Mol Genet Metab 104, S10-18.

6. Masoro, E. J. 2000. Caloric restriction and aging: an update. Exp Gerontol 35, 299-305.

7. Masoro, E. J. 2005. Overview of caloric restriction and aging. Mech Ageing Dev 126, 913-922.

8. Ntambi, J. M., Miyazaki, M. and Dobrzyn, A. 2004. Regulation of stearoyl-CoA desaturase expression. Lipids 39, 1061-1065.

9. Okada, K., Kasahara, H., Yamaguchi, S., Kawaide, H., Kamiya, Y., Nojiri, H. and Yamane, H. 2008. Genetic evidence for the role of isopentenyl diphosphate isomerases in the mevalonate pathway and plant development in Arabidopsis. Plant Cell Physiol 49, 604-616. 
10. Park, J., Kwon, Y. -S., Lee, E. and Kwon, K. 2014. Expressional analysis of two genes (Got1 and Mat1) up-regulated by starvation stress. J Life Sci 24, 686-693.

11. Pond, W. G., Ellis, K. J. and Schoknecht, P. 1992. Response of blood serum constituents to production of and recovery from a kwashiorkor-like syndrome in the young pig. Proc Soc Exp Biol Med 200, 555-561.

12. Schutz, Y. 2011. Protein turnover, ureagenesis and gluconeogenesis. Int J Vitam Nutr Res 81, 101-107.
13. Steinberg, S. J., Raymond, G. V., Braverman, N. E., Moser, A. B. and Moster, H, W. 2006. Peroxisome Biogenesis Disorders, Zellweger Syndrome Spectrum. GeneReviews. http://www.ncbi.nlm.nih.gov/bookshelf/br.fcgi?book=gene \&part $=$ pbd.

14. Zheng, W. 1., Sun, F., Bartlam, M., Li, X., Li, R. and Rao, Z. 2007. The crystal structure of human iso pentenyl diphosphate isomerase at $1.7 \mathrm{~A}$ resolution reveals its catalytic mechanism in isoprenoid biosynthesis. J Mol Biol 366, 1447-1458.

\section{초록 : 영양고갈-스트레스에 의해서 하강발현하는 유전자 $(S c d$ 과 $/ d i)$ 의 분석}

조준호 $^{1} \cdot$ 권영숙 $^{2} \cdot$ 김동일 $^{3} \cdot$ 김복조 $^{4} \cdot$ 권기상 $^{4 *}$

( ${ }^{1}$ 인제대학교 해운대백병원 응급의학과, ${ }^{2}$ 중부대학교 간호학과, ${ }^{3}$ 경운대학교 보건바이오학과, ${ }^{4}$ 경 운대학교 임상병리학과)

Starvation에 의해서 down-regulation 되는 유전자 10개를 얻었다(Comt, RGN, Scdl, Temt, Idi1, Fabp5, Car3, Cyp2c70, Pinx1, Poldip3). 이들은 starvation에 의한 대사변화의 대부분은 liver와 관련된 것으로 볼 수 있다. Starvation중에 물 공급은 암수 동일하게 apoptosis, autophage, endoplasmic reticulum quality control (ERQC)유 도에 영향을 미치지 않았다. 이 같이 starvation에 의해서 down-regulation되는 유전자발현조절이 liver에 국한된 것이라기보다는 개체의 항상성유지에 관련 많은 pathway가 관련되어있는 것으로 판단된다. 장기간의 간혈 starvation은 glucose소비가 많은 brain과 면역기능조절에 중요한 thymus의 정상기능에 영향을 미칠 수 있는 것으로 보인다. 유전자 $S c d 1$ 의 경우는 우보다가 송이 민감한 반응을 보이는 것으로 보아 우/송의 성 특이적인 대사에 starvation과 $\mathrm{NaCl}$ 이 밀접한 관계가 있는 것으로 보인다. Starvation시 물 공급도 중요하지만 개체의 항상성유지 에 $\mathrm{NaCl}$ 공급이 중요하다는 결과를 얻었다. 